\title{
Using the Theory of Planned Behavior to Predict the Adoption of Heat and Flood Adaptation Behaviors by Municipal Authorities in the Province of Quebec, Canada
}

\author{
Johann Jacob*(D), Pierre Valois (D) and Maxime Tessier \\ Observatoire Québécois de l'Adaptation aux Changements Climatiques (OQACC), Faculté des Sciences de \\ L'éducation, Université Laval, Québec, QC GIV 0A6, Canada; pierre.valois@fse.ulaval.ca (P.V.); \\ maxime.tessier@fse.ulaval.ca (M.T.) \\ * Correspondence: johann.jacob@fse.ulaval.ca; Tel.: +1-418-656-2131 (ext. 408522)
}

check for

updates

Citation: Jacob, J.; Valois, P.; Tessier, M. Using the Theory of Planned Behavior to Predict the Adoption of Heat and Flood Adaptation

Behaviors by Municipal Authorities in the Province of Quebec, Canada. Sustainability 2021, 13, 2420. https:// doi.org/10.3390/su13052420

\section{Academic Editors:}

Santiago Fernandez-Rodriguez and José María Maya-Manzano

Received: 13 January 2021

Accepted: 18 February 2021

Published: 24 February 2021

Publisher's Note: MDPI stays neutral with regard to jurisdictional claims in published maps and institutional affiliations.

Copyright: (c) 2021 by the authors. Licensee MDPI, Basel, Switzerland. This article is an open access article distributed under the terms and conditions of the Creative Commons Attribution (CC BY) license (https:/ / creativecommons.org/licenses/by/ $4.0 /)$.

\begin{abstract}
The aim of this study is to identify which psychosocial factors of the theory of planned behavior better predict and explain the adoption of heat and flood adaptation behaviors by municipal authorities in the Province of Quebec, Canada, and to explore the cognitive structures motivating municipal officers to adopt adaptation behaviors. The results of structural equation analyses showed that municipal authorities' attitude toward the adoption of adaptation behaviors (i.e., the degree to which the performance of an adaptive behavior is positively or negatively valued by municipal officers) and perceived control (barriers) over adaptation behaviors significantly contributed to the prediction of readiness to adopt the behavior.
\end{abstract}

Keywords: adaptation; climate change; organization; psychosocial; theory of planned behavior

\section{Introduction}

With climate change, the frequency and intensity of certain climate hazards such as heat waves, floods, and vector-borne diseases will increase, leading to greater impacts on several levels, in particular on global health, ecological and social systems, built environments, etc. As manifestations of climate change multiply, effective responses must integrate adaptation, mitigation, and sustainable development paths [1]. Certain climate risks are more present in urban areas and translate into significant impacts for cities and their communities: heat wave impacts, including increased premature deaths [2], especially among the elderly [3]; air pollution; food insecurity; undernutrition; and mental health problems [4]. Other climate risks concentrated in urban areas include increased extreme precipitation, flooding that strains overloaded drainage infrastructure networks, landslides, deficits in water supply, forest fires in greater intensity due to prolonged episodes of drought, and rising sea levels that aggravate flooding and storm surges in coastal areas $[5,6]$.

The Paris Agreement identifies cities as important actors for climate mitigation and adaptation [7]. In the adaptation process, the importance of action by local authorities and stakeholders such as municipalities has been repeatedly emphasized [8-11]. While local governments cannot solve the problems caused by climate change on their own [12-14], municipalities can adopt regulatory or non-regulatory measures for climate change adaptation in key areas: the environment (e.g., water supply, sewer and water purification, drainage); built environments (e.g., construction materials, on-site rainwater management); urban planning regulatory tools (e.g., zoning, new residential sector planning, conservation of wetlands, creation of green spaces), and security (e.g., disaster risk management, emergency measures planning) [15-18].

The importance of climate change adaptation actions at the municipal level is supported by benefits such as the health and well-being of the population, the value of 
ecological goods and services, and reduction of losses to the built environment [19-24]. Several studies assess the progress of adaptation goals at the national level or across major cities, notably to determine whether or not funds allocated to adaptation research and practice translate into concrete and effective actions [25]. However, an overview of this literature shows that few studies have assessed the progress of adaptation efforts at the local level [15,26-28].

While adaptation reporting can be a valuable source of information for documentation of adaptation actions implemented by municipalities or civil society organizations, it is an imperfect proxy of adaptation on the ground [26]. First, such assessments rely mainly on public documents, such as adaptation and emergency plans and information on municipal websites $[27,29,30]$. This situation creates a coverage issue by overlooking any municipalities that do not publish this kind of material. Secondly, most of these studies are based on small samples [27,31], which makes it difficult to make inferences to a larger scale [26]. Third, while other studies used survey methodology to produce large-scale assessments of adaptation [32,33], their methodologies did not necessarily allow good representativity of the municipalities of the studied region. For example, Carmin et al. [33] limited their sample to cities that are members of the ICLEI network. Moreover, Guyadeen et al. [34] evaluated the strengths and weaknesses of the climate change plans of 63 of the most populous communities across Canada. While offering a large-scale portrait, this study focused on the most populous municipalities, which are possibly better organized in terms of climate action. In sum, there is a need for research with methods that aim to produce a more representative portrait of municipal adaptation to infer results on a larger set.

Finally, even if municipalities are developing climate change plans, adaptation reporting and plan quality research fall short of identifying why some municipalities are doing better than others in the implementation of their plans. For example, differences between municipalities may relate to dimensions such as cognition about the threats represented by climate change [35], as well as the role of various psychosocial antecedents of the individual adaptation motivations or adaptation beliefs of decision-makers in organizations [36]. Thus, in order to better understand why some municipalities adopt more adaptive practices than others, there is a need to conduct a study integrating a psychosocial perspective in the measurement of adaptation effort progress at the local level.

A growing literature has shown that psychosocial factors such as perception of climate risk, cognitive and motivational factors (e.g., values, beliefs), and social factors (e.g., norms, social pressures, obligations) [37-41] can lead individuals to adopt specific behaviors that might protect them from the consequences of a climatic hazard, and therefore contribute to a better understanding of the psychosocial processes by which adaptation occurs. This has led some authors to say that greater emphasis should be placed on behavioral adaptation (which focuses on a range of psychosocial factors to predict motivation to adopt adaptation behaviors) [35,42-44]. At the organizational level, adaptation involves learning and adjustments tied to different organizational processes (risk perception, evaluation of solutions, enactment, feedback). While an organization's level of adoption of adaptive actions will be shaped by its institutional context (i.e., by external social, cultural, political, and economic structures and processes), it will also be influenced by factors such as perceptions, framing of risks, and the capabilities of the organization [35]. For instance, factors such as experiences of climate extremes can have an influence on how people inside organizations make sense of climate change, and from there can affect organizational adaptation choices [1,45-47]. In a sense-making process, interpretations of an experience of climate extreme will be influenced by the frames of reference used by a person to understand this experience [46], such as organizational ideology (e.g., beliefs about cause-effect relationships, preferences for certain outcomes, and expectations of appropriate behaviors [45,48].

Differences between municipalities regarding the adoption of adaptation actions can also relate to psychological determinants. As mentioned by Grothmann, Grecksch, Winges, 
and Siebenhüner [36], "psychological or subjective factors like individual adaptation motivation or adaptation belief of a decision-maker in an organisation are a result of 'subjective' perceptions of 'objective' climate change projections, organizational contexts (e.g., financial resources, institutional entitlements, negotiations between different actors in an organization) and the wider institutional environment influencing and shaping both the organizational roles and responsibilities as well as the individuals' motivations and beliefs" (p. 3374).

Therefore, in order to design effective behavior-change interventions, it is not only important to determine whether adaptation measures promoted by public authorities are being effectively adopted at the organizational level (e.g., at the municipal level), but also to determine the reasons why some cities are adapting more than others. To our knowledge, the latter type of research, which models all of the psychological and organizational processes leading to the adoption of adaptation measures, has not been sufficiently conducted at the municipal level [49].

Empirical studies based on psychosocial models that predict behaviors, such as the theory of planned behavior, or TPB [50], have made their way into climate change literature to help researchers understand what drives adaptation actions [40,51-54]. However, use of such models in research at the organizational level is still rare $[44,55,56]$. The usefulness of the TPB for predicting behaviors in various contexts has been repeatedly demonstrated $[57,58]$, as has its usefulness for better understanding the adoption of pro-environmental behaviors, that is, behaviors that encourage or foster sustainable, climate-healthy, and nature-enhancing choices [59].

The purpose of the current study is twofold. Our first aim is to use the TPB to identify which psychosocial factors (attitudes, perceived social norms, and perceived control or barriers over behaviors) better predict and explain the adoption of heat and flood adaptation behaviors by municipal authorities. Our second aim is to explore the cognitive structures motivating municipal officers to adopt adaptation behaviors, that is, the beliefs forming their attitude, perception of social norms, and perceived control or barriers over these behaviors.

\section{The Theory of Planned Behavior (TPB)}

The TPB aims to predict and understand human social behavior. Usually applied at the individual level, it can also be useful at the organizational level [55]. In fact, consistent with the upper echelons perspective [60], we postulated that managers and senior professionals working for municipalities can account for organizational adaptation. There is little doubt that such upper level staff have the ability to make decisions regarding adoption or promotion of adaptation actions, or decisions that could have important strategic implications for their organizations (e.g., refusing or requesting modifications to a construction project deemed too flood-prone; revising regulations in order to protect shorelines, coastlines, and flood plains; or acquiring riparian properties to protect them from real estate development). The same is true regarding organizational risk perception. As noted by Zhang et al., "top management cognition can causally determine organizational strategic choices and outcomes" [61] (p. 378). In the same vein, Daft and Weick [62] "specifically stress the role of top management in synthesizing information from nested subsystems and formulating the interpretation for the organizational system as a whole" [61] (p. 378). This contention is also supported by Linnenluecke et al.: "Research has demonstrated that key decision-makers such as executives, managers, and change agents at lower levels of the organization can have an important role in influencing their firm's pro-environmental behavior" [63] (p. 400). Based on these views and using the theory of planned behavior, we questioned managers and senior professionals working for municipalities to document their organizational adaptation behavior.

According to the theory of planned behavior, behavioral intention is determined by three behavior-centered factors: attitudes toward the behavior, subjective or social norms concerning the behavior, and perceived control over the behavior [57]. Thus, in line with 
the TPB framework, we postulate that municipal officers' intention to adopt adaptation behaviors $(\mathrm{AB})$ should increase to the extent that (a) they hold favorable attitudes toward adaptation behaviors (i.e., whether performing the adaptive behavior is positively or negatively valued by municipal officers, for example, the crucial role of municipalities in reducing the population's vulnerability to heat waves and its territory's vulnerability to flooding); (b) they believe that significant others have expectations around or support $A B$ (e.g., the municipality's population; regional, provincial, or federal public health agencies); and (c) they perceive that the municipality has control over the adoption of the $A B$ (i.e., the required capacities to adapt such as information on methods and techniques to put in place, clear mandates to act, availability of time, funding, cooperation, etc.).

In line with the TPB, it is expected that the perception of behavioral control or barriers over $\mathrm{AB}$ should moderate the effect of intention on the adoption of $\mathrm{AB}$ [64]. This means that municipal officers tend to act in accordance with their intentions when they believe that their municipality has control over the adoption of a municipal AB. Conversely, when municipal officers feel that they have little control over the adoption of an $A B$, they do not tend to act in accordance with their intentions [65]. This moderating effect is illustrated in Figure 1 by the dashed-line arrow.

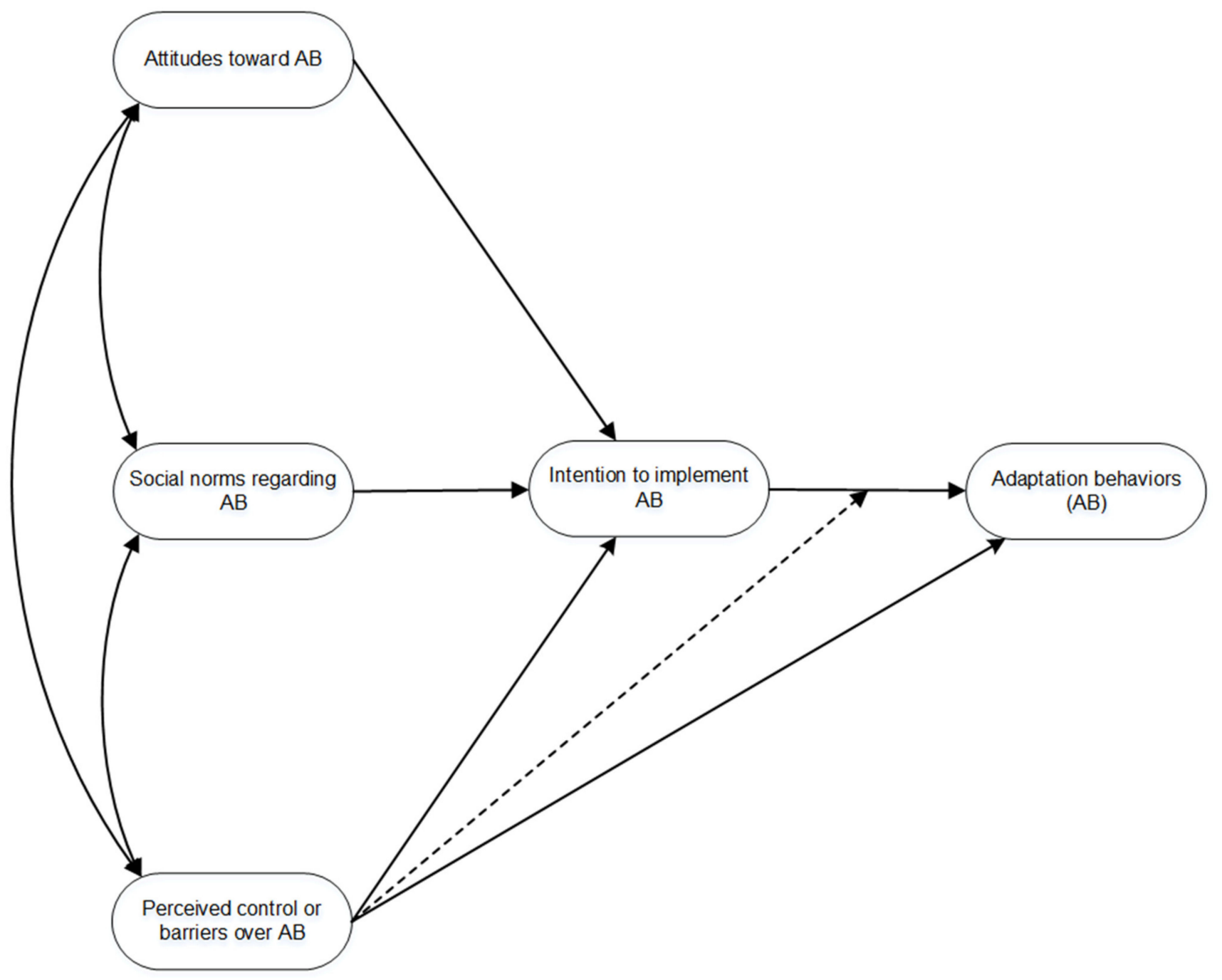

Figure 1. The theory of planned behavior model. 


\section{Materials and Methods}

\subsection{Participants}

In the current study, the target population included 1218 municipal entities located in Quebec (Canada) (see Figure 2). In this province (total population: 8.6 million), there are two levels of municipal organization: the local and the supralocal. The local level notably includes municipalities constituted under general municipal regimes, which make up the bulk of Quebec's municipal entities $(\mathrm{N}=1110)$. We also included Montreal boroughs at the local level $(\mathrm{N}=19)$. At the supralocal level, regional county municipalities or RCM (municipalités régionales de comtés-MRC) represent all local municipalities within an RCM's territory. RCMs $(\mathrm{N}=87)$ are typically directed by a council made up of the mayor of each of the local municipalities in that territory. This council is headed by a prefect, usually elected by members of the council. RCMs have power in terms of planning land use as well as in terms of risk coverage. The supralocal level also includes the only two metropolitan communities in the province of Quebec: Montreal (population: 3.8 million) and Quebec City (population: 0.79 million), representing, respectively, 82 and 28 municipalities located within their territories. As with the RCMs, metropolitan communities exercise powers in several areas, including land use planning [66].

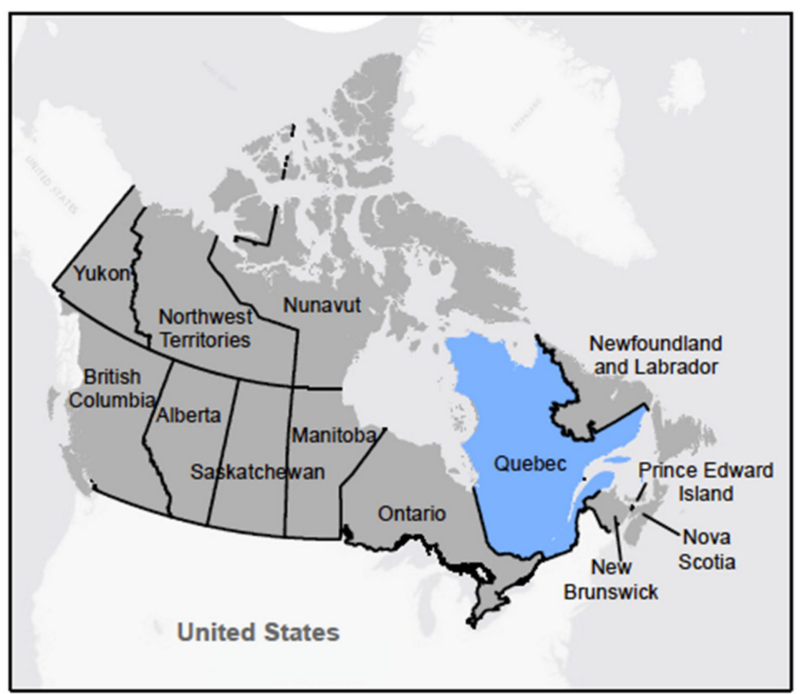

Figure 2. The province of Quebec (Canada).

We sent municipal officers working in the following positions an invitation to complete an online questionnaire (via LimeSurvey): (i) urban planning, (ii) public works (Municipal officers of public works were not surveyed in the RCMs, since most of them work for the municipalities), (iii) civil protection. If the first person contacted believed that another person in the organization should respond to the survey, she was asked to transfer the questionnaire.

A total of 197 municipal entities (including municipalities, boroughs of Montreal, RCMs, and metropolitan communities) participated in this study (response rate of 16.17\%). This means that for 197 of the 1218 entities, at least one of the municipal officers contacted completed the survey. When more than one respondent completed the survey for the same entity $(46 / 197 ; 23.35 \%)$, we calculated the average of the responses. The respondents were responsible for development and land use planning $(38.08 \%)$, urban planning $(36.54 \%)$, the environment $(30.38 \%)$, or municipal inspection $(25.00 \%)$ (more than one answer was possible for this question). For $60.41 \%$ of the participants, the highest educational level obtained was a university degree (undergraduate: $31.84 \%$; graduate: $28.57 \%$ ). Over half of the participants (55.51\%) were $40-59$ years old, $31.84 \%$ were aged 30 or under, and $11.84 \%$ were over 60 (0.81\% did not respond). Finally, our sample included participants who had been employed by their current municipality for different lengths of time: $27.65 \%$ for less 
than three years, $24.62 \%$ for $3-10$ years, $23.48 \%$ for $11-20$ years, and $23.48 \%$ for more than 20 years $(0.76 \%$ did not respond).

\subsection{Theory of Planned Behavior Questionnaire}

The questionnaire administered to municipal officers assessed TPB constructs. To review the relevance, completeness, and formulation of the selected indicators, it was first submitted for feedback to representatives of the City of Quebec, the Association des aménagistes régionaux du Québec (Association of Regional Planners of Quebec), the ministère des Affaires municipales et de l'Occupation du territoire (Ministry of Municipal Affairs, Regions and Land Occupancy), the Fédération québécoise des municipalités (Quebec Federation of Municipalities), and the Union des municipalités du Québec (Quebec Union of Municipalities). The questionnaire was developed based on a review of scientific and grey literature recommendations for preparatory behaviors or actions supporting adaptation and adaptation interventions and barriers to adaptation.

\subsubsection{Dependent Variables: Behavioral Intention and Adaptation Behavior}

Intentions to implement adaptation behaviors. Intentions were assessed by computing the mean response to the following three items (reliability Cronbach alpha $=0.92$ ). The reliability Cronbach alpha provides an estimate (ranging from 0 to 1 ) of the homogeneity (internal consistency) of a measurement instrument or latent variable composed of a set of items that all putatively measure the same construct or concept. A Cronbach alpha value close to 1 indicates a high level of internal consistency among the items measuring the construct (i.e., its reliability). As part of my duties: (INT-1) I intend to prioritize the preparation for heat waves or flooding over the next three years; (INT-2) I am determined to take action to prioritize the preparation for heat waves or flooding over the next three years; (INT-3) I plan to regularly propose measures to prioritize the preparation for heat waves or flooding over the next three years. Responses were provided on four-point scales ranging from "Strongly disagree" (+1) to "Strongly agree" $(+4)$.

Adaptation behaviors. Given the important number of adaptation behaviors or initiatives that municipal officers can adopt (e.g., promoting the planting, conservation, and protection of trees in urban areas; increasing the use of permeable and porous materials for roads, parking lots, and sidewalks; informing the population about the dangers and actions to take in the event of heat waves or floods), the operationalization and measurement of individual or organizational adaptation is not an easy task. If the research population had been a single group of municipal officers (e.g., urban planners), it would have been possible to use an index of multiple specific behaviors and create an adaptation index for the dependent variable. However, given the objective to include a large sample of respondents, a compromise was made to use more general adaptation behaviors, which allowed integration of responses from three categories of municipal workers (urban planners, public works officers and civil protection officers). These more general adaptation behaviors have been linked to the mainstreaming of concern about climate change into ongoing organizational strategies, activities, and processes [67-71], as well as mobilizing partners and developing partnerships [72-74].

Therefore, the implementation of adaptation behaviors was assessed by computing the mean of the following six responses (reliability Cronbach alpha $=0.91$ ): Since taking up your current position, how often do you think you have personally practiced each of the following behaviors in your municipality? (COMP-1) Address an issue of preparation for heat waves or flooding in communication with your supervisors (meeting, written notes, informal discussion, etc.); (COMP-2) Recommend that your supervisors adopt a heat wave or flood preparation measure (written or verbal recommendation); (COMP-3) Address an issue of preparation for heat waves or floods in communication with your fellow service personnel; (COMP-4) Ask your fellow service personnel to take into account the consequences of heat waves or flooding as part of a mandate; (COMP-5) Address an issue of preparation for heat waves or floods in communication with another organization 
(regional partner, private company, promoter, etc.); (COMP-6) Get personally involved in a heat wave or flood preparation project in your municipality. Responses were provided on four-point scales ranging from "Never" $(+1)$, "Rarely, i.e., less than once a year" $(+2)$, "Occasionally, i.e., once or twice a year $(+3)$, to "Regularly, i.e., three or more times a year" (+4).

\subsubsection{Precursors of Behavioral Intention and Adaptation Behavior}

Attitudes toward the implementation of adaptation behaviors. Responses to three items were used as reflective indicators of municipal officers' attitudes toward the implementation of adaptation behaviors (reliability Cronbach alpha $=0.65$ ). Participants rated each of the following items on a four-point scale ranging from "strongly disagree" $(+1)$ to "strongly agree" (+4). In general, the majority of elected officials in our municipality believe that: (ATT-1) municipalities have an important role to play in planning for heat waves and flooding; (ATT-2) reducing the population's vulnerability to heat waves and its territory's vulnerability to flooding should be among our municipality's priorities; and (ATT-3) methods and techniques currently available to prepare for heat waves (greening, rainwater management, etc.) and for flooding (protective works, rainwater management devices, etc.) can effectively help protect the population's safety and health."

Perceived social norms regarding adaptation behaviors. Responses to four questions were used to assess municipal officers' perception of social norms related to the adoption of adaptation behaviors (reliability Cronbach alpha $=0.72$ ). Participants rated each of the following items on a four-point scale ranging from "strongly disagree" $(+1)$ to "strongly agree" (+4): (N-1) Some Quebec municipalities, comparable to ours, prioritize preparing for heat waves or flooding; (N-2) Regional bodies to which this municipality belongs have high demands regarding our municipality's actions to prepare for heat waves or flooding; (N-3) Provincial and federal governmental authorities have high demands regarding our municipality's actions to prepare for heat waves or flooding; and (N-4) The population of our municipality has high expectations regarding our action to prepare for heat waves or flooding.

Perceived control (barriers) over the implementation of adaptation behaviors. The questionnaire addressed eight control factors or barriers (reliability Cronbach alpha $=0.74$ ). Participants rated each of the following eight items on a four-point scale ranging from "strongly disagree" (+1) to "strongly agree" (+4): (B-1) The role of municipalities in preparing for heat waves or for flooding is unclear; (B-2) There is no consensus among specialists on the methods and techniques to be put in place to prepare for heat waves or flooding; (B-3) There is little concrete or useful information available on preparation for heat waves or flooding in the official documentation; (B-4) Employees in our municipality are too overburdened with their basic responsibilities to spend time preparing for heat waves or flooding; (B-5) Actions to prepare for heat waves or flooding are in areas beyond the scope of the municipalities; (B-6) It is difficult to achieve joint action with the other actors in our region in terms of preparing for heat waves or flooding; (B-7) It is difficult to have an internal budget in place to fund measures to prepare for heat waves or flooding; (B-8) There is resistance within the municipality which make it difficult to implement new ways of doing things (innovation) in terms of preparation for heat waves or flooding.

\subsection{Statistical Analysis}

The statistical analyses were performed in two steps. In the first step, we tested the TPB to identify psychosocial factors that predict and explain adoption of heat wave and flood adaptation behaviors by municipal authorities (Objective 1). More specifically, we tested two hierarchical TPB models: the first tested the hypothesized paths between TPB constructs when the intention-adaptation behavior relationship was not moderated by perceived control over the behaviors, and the second model included this moderating effect. The aim of this final analysis was to specifically verify whether municipalities that have more control over the adoption of a municipal $\mathrm{AB}$ tend to act more in accordance with their 
intentions than municipalities with less control. In the second step, regression analyses aimed to explore the cognitive structures underlying the formation of the identified key psychosocial factors held by municipal officers that affect their intention to adopt adaptation behaviors and their actual adoption of adaptation behaviors (Objective 2).

Structural equation modeling (SEM) with Mplus 8.0 [75] were used to identify the factors that led municipal authorities to adopt adaptation behaviors. SEM "can be viewed as a combination of factor analysis and regression or path analysis" [76]. It entails representing the relationships between the theory's constructs measured with appropriate observed variables or indicators [77]. The compatibility of the observed associations with the theoryimplied associations is then verified to test the theory. Models analyzed with SEM generally assume probabilistic causality, not deterministic causality [78].

It is recommended that multiple indicators (rather than a single indicator) be used in SEM to measure each theoretical construct. This methodological strategy usually produces more reliable and valid scores [78]. However, in the present study, it was not possible to consider each item used to measure a given theoretical construct as an individual indicator of that construct, as the model had too many parameters to estimate for the number of observations. This would have resulted in unreliable estimations of the parameter of the underlying model. For this reason, parcels were used to define constructs. Parcels represent the sum or mean of the responses to several questions designed to measure the same construct. In the present study, each parcel represented a random subset of scale items [79], except for two constructs: attitudes toward $A B$ and intention to implement $A B$, for which each of the three items was used as single indicator. Parcels were created simply by dividing variables in half. Each item was numbered, and then distributed alternately in each parcel according to whether their number was even or odd. Maximum likelihood estimation with robust standard error (MLR) was employed, as this method is robust with respect to non-normal distribution of scores [75].

Given the known oversensitivity of the chi-square test to sample size, we assessed the model fit with sample-size-independent fit indices: the comparative fit index (CFI), the Tucker-Lewis index (TLI), and the root mean squared error of approximation (RMSEA). According to conventional rules of thumb [78,80], CFI and TLI values ranging from 0.90 to 0.94 indicate an acceptable model fit, while values greater than or equal to 0.95 indicate an excellent fit. For the RMSEA, model fit is acceptable if the value is between 0.08 and 0.061 , and excellent if it is less than or equal to 0.06 .

Next, we applied stepwise regression analyses, using the PHREG procedure in SAS Release 9.4, to identify the specific beliefs (i.e., the items used to measure attitudes, perceived social pressure and perceived control or barriers over behaviors) that had a significant influence on municipal authorities' intention to adopt $A B$ and their adaptation behavior. We set the entry significance level to $p$-values $<0.25$ and the retain significance level to $p$-values $<0.15$.

\section{Results}

\subsection{Descriptive Statistics}

Table 1 presents means and standard deviations for each measure. Municipal officers gave themselves a moderate score for the adoption of adaptation behaviors $(\mathrm{M}=2.09$ out of a maximum score of 4). Regarding the other TPB variables, respondents reported moderately strong intentions to adopt $\mathrm{AB}(\mathrm{M}=2.67$ out of a maximum score of 4$)$, a favorable attitude toward the adoption of $\mathrm{AB}(\mathrm{M}=2.92$ out of a maximum score of 4), moderately high social pressure (e.g., the belief that the municipality's population and public health agencies had expectations regarding adaptation actions; $\mathrm{M}=2.46$ out of a maximum score of 4$)$, and moderately high perception of barriers to the adoption of $A B(M=2.74$ out of a maximum score of 4). In line with prior research [81], the results of correlations showed that all TPB precursors were significantly correlated with the intention to adopt or adoption of $\mathrm{AB}$ (see Table 1). As expected, correlations were negative between perceived barriers and intention to adopt $\mathrm{AB}$ and the actual adoption of adaptation behaviors. 
Table 1. Means, standard deviations, and correlations between theory of planned behavior (TPB) variables.

\begin{tabular}{lcccccccc}
\hline \multicolumn{1}{c}{ Variables } & \# of Items & $\boldsymbol{M}$ & SD & $\mathbf{1}$ & $\mathbf{2}$ & $\mathbf{3}$ & $\mathbf{4}$ & $\mathbf{5}$ \\
\hline (1) Adaptation & 6 & 2.09 & 0.83 & - & & & & \\
behaviors & 3 & 2.67 & 0.72 & $0.38^{* *}$ & - & & \\
(2) Intention & 3 & 2.92 & 0.50 & $0.20^{* *}$ & $0.40^{* *}$ & - & \\
(3) Attitudes & 4 & 2.46 & 0.58 & $0.36^{* *}$ & $0.34^{* *}$ & $0.46^{* *}$ & - & \\
(4) Social norms & 8 & 2.74 & 0.44 & $-0.36^{* *}$ & $-0.28^{* *}$ & $-0.34^{* *}$ & $-0.35^{* *}$ & - \\
(5) Perceived & 8 & & & & & \\
control (barriers) & & & & & & &
\end{tabular}

Notes. \# Theoretical range for all variables: [1-4]. ${ }^{* *} p<0.01$.

\subsection{Testing of the TPB Model}

First, we tested the TPB model in which the intention-behavior relationship was not moderated by perceived control over the behavior. The fit of this model to the data was acceptable: CFI $=0.942$, TLI $=0.916$, and RMSEA $=0.073$. Results showed that the model accounted for $30.6 \%$ of the variance in municipal authorities' behavioral intentions to adopt $\mathrm{AB}$ and $22.1 \%$ of the variance in actual $\mathrm{AB}$ adoption (see Figure 3). Results revealed that authorities' intention to adopt $\mathrm{AB}(\gamma=0.28, p<0.01)$ and their perceived barriers over the behavior $(\gamma=-0.30, p<0.01)$ were significant predictors of their actual adoption of $\mathrm{AB}$. Results also revealed that among the three assumed psychosocial determinants of behavioral intentions, only municipal authorities' attitudes towards the adoption of $A B$ was significantly associated with it $(\gamma=0.39, p<0.05)$.

We also tested the same model with the addition of a path that would verify whether the relationship between authorities' intentions to adopt $A B$ behaviors was moderated by their perceived control (barriers) over adaptation behaviors. Results showed that the intention-behavior relationship was not significantly moderated by perceived control (barriers) $(\gamma=-0.001, p<0.994)$. No model fit information is given when a model includes an interaction term. Therefore, we retained the model without the moderating effect of perceived behavioral control or barriers on the intention-behavior relationship.

\subsection{Specific Beliefs Associated with the Adoption of Adaptive Behavior}

Results of the structural equation modeling analyses showed that only municipal authorities' attitudes toward the adoption of $\mathrm{AB}$ was positively and significantly associated with their intentions to adopt $A B$, and that municipal authorities' perceived barriers over $A B$ was negatively and significantly associated with adoption of $A B$. Next, we performed two stepwise regression analyses to identify (a) the specific key beliefs underlying municipal authorities' attitudes toward the adoption of $A B$ (three beliefs were used to measure attitudes) that had an effect on their intention to adopt $A B$, and (b) the specific key beliefs underlying municipal authorities' perceived barriers over $\mathrm{AB}$ (eight beliefs were used to measure perceived barriers) that had an effect on their decision to adopt $A B$.

Results from the first stepwise regression analysis revealed that the three attitudinal beliefs accounted for $24.1 \%$ of the variance in municipal authorities' intentions to adopt $\mathrm{AB}$. The effects of two of these beliefs were statistically significant: "Municipalities have an important role to play in planning for heat waves and flooding" $(\beta=0.248, p<0.01)$; and "Reducing the municipality population's vulnerability to heat waves and its territory's vulnerability to flooding should be among our municipality's priorities" ( $\beta=0.500$, $p<0.01$ ).

Results from the second stepwise regression analysis showed that the eight perceived barriers to adoption of $\mathrm{AB}$ explained $11.5 \%$ of the variance in municipal authorities' adaptation behavior. The effect of one of these beliefs was statistically significant: "It is difficult to have an internal budget in place to fund measures to prepare for heat waves or flooding" $(\beta=-0.220, p<0.05)$. 


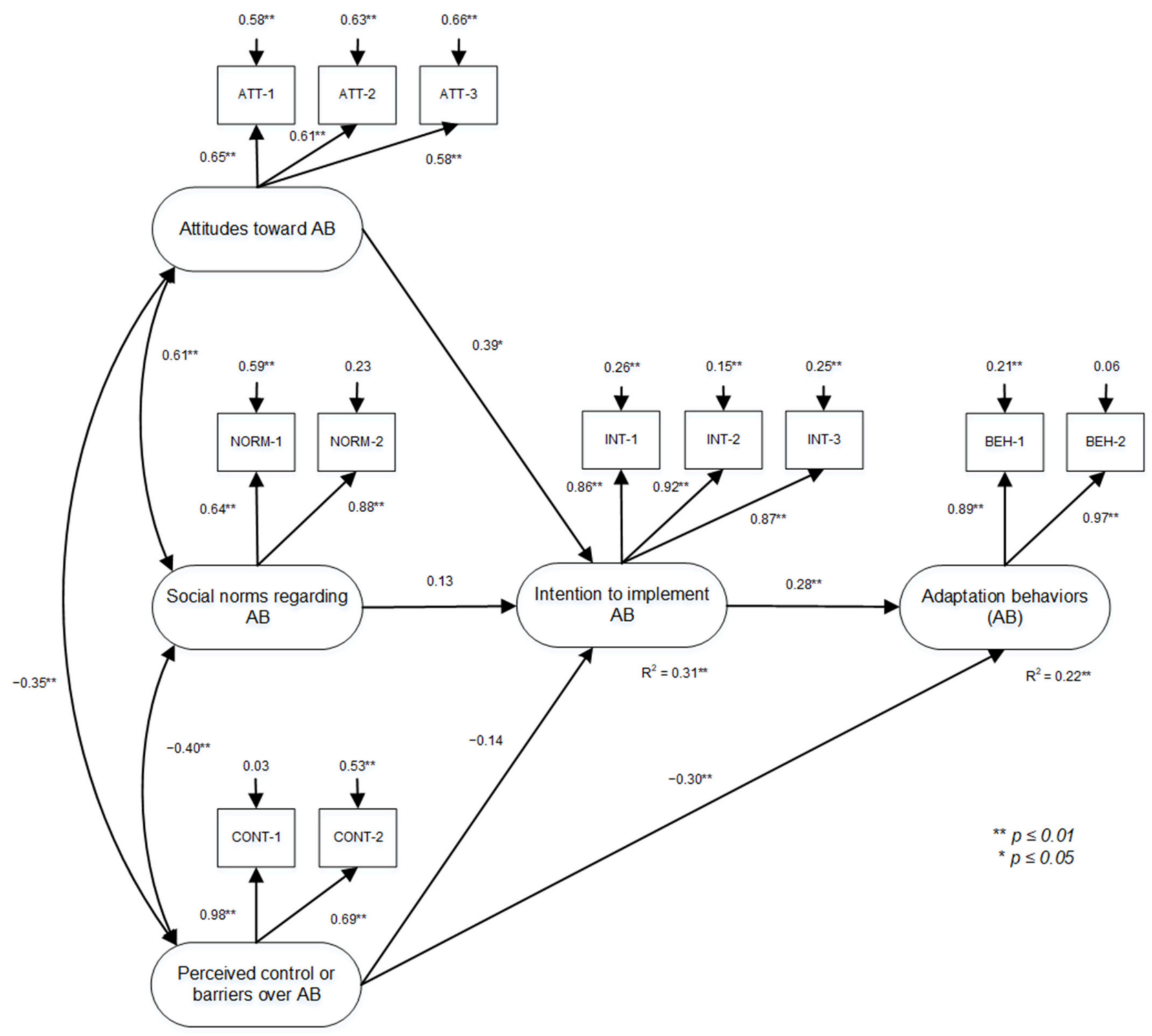

Figure 3. TPB variables predicting adoption of adaptation behaviors.

\section{Discussion}

The aims of this study were to identify which psychosocial factors (attitude, perceived social norms, and perceived control or barriers over the behavior) better explain the adoption of heat and flood adaptation behaviors by municipal authorities, and to explore the cognitive structures motivating municipal officers to adopt adaptation behaviors, that is, the beliefs forming their attitudes, perception of social norms, and perceived control or barriers over these behaviors.

Our results showed that in the province of Quebec, municipal officers' intention to implement $\mathrm{AB}$ and their perceived barriers over adaptation behaviors were significant predictors of the adoption of these behaviors. They also revealed that municipal officers' intentions to adopt $\mathrm{AB}$ are mainly influenced by attitudinal considerations. More precisely, their attitude toward adaptation behavior was the only determinant of the TPB variables that had a significant effect on municipal officers' behavioral intentions to adopt $A B$. Perceived social norms and perceived control over $\mathrm{AB}$ did not. 
Based on these results, it is important that municipal officers reflect on certain questions around the adaptation process at the municipal level (e.g., preferences for certain adaptation measures, the expectation that they will be successful, the subjective value associated with prospective results, and the level of threat of climate hazards). This reflection is essential, as the formation of positive beliefs around $\mathrm{AB}$ can foster the development of positive attitudes toward climate action. An individual is likely to have a favorable attitude toward a behavior if he/she can see its benefits. For instance, municipal officers might see the reduction of the municipal population's vulnerability to heat waves and the territory's vulnerability to flooding as a benefit associated with the adoption of adaptation behaviors. Thus, it is essential that municipal officers consider such questions as it might help trigger climate action.

This result has important implications for the design of awareness or educational interventions aiming to foster the adoption of adaptation behaviors at the municipal level. Most interventions are based on the premise that transmitting knowledge about good adaptation practices or about the level of climate risk involved will lead people to make the right decisions. According to such a premise, if municipal officers know, for example, that municipalities are at risk and what the municipalities can do about it, they will be more likely to adopt adaptation behaviors $[40,82,83]$. However, this premise does not take into account the important role of primary beliefs in the determination of a municipal officer's decision to adopt a given adaptation behavior. Beliefs reflect the information people possess relevant to a given behavior, whether that information is accurate or not [84] (p. 316). According to Fishbein and Ajzen [84], a background factor (e.g., demographic characteristics, personality traits, exposure to information, knowledge, perception of being at risk, etc.) "will be associated with the performance of a behavior only to the extent that the background factor is related to the behavioral, normative, or control beliefs that serve as the determinants of the behavior under consideration" (p. 225). This means that in order to be effective, an intervention should not solely rely on the message that municipalities are at risk regarding the impacts of climate hazards, but rather, should target and modify the behavior-relevant beliefs that serve as determinants to adopting specific adaptation measures. These particular beliefs with respect to specific adaptation behaviors must be identified prior to the design of an awareness or educational intervention aimed at promoting the adoption of adaptation behaviors.

In the case of adaptation behaviors by Quebec municipal officers, interventions that aim to foster adaptation at the level of municipal authorities would be more effective if they were designed to reinforce supportive attitudinal beliefs and counter negative ones [84] (p. 332). For instance, examination of the key beliefs of municipal officers showed that municipal officers who believed that "municipalities have an important role to play in planning for heat waves and flooding" and that "reducing the municipality population's vulnerability to heat waves and its territory's vulnerability to flooding should be among our municipality's priorities" are more likely to develop a positive intention to adopt adaptation behaviors and to carry out this intention in action.

While the effect of municipal officers' attitudes on their decision to adopt $A B$ is mediated by their intentions, our results show that perceived barriers can directly prevent the performance of adaptation behaviors without having a direct effect on their intentions. These results suggest that in some situations, municipal officers' attitudes (i.e., their positive beliefs regarding $\mathrm{AB}$ ) could provide sufficient motivation to form a favorable behavioral intention and to carry on in the adoption of adaptation behaviors. In other situations, if perceptions of barriers to the adoption of $\mathrm{AB}$ (i.e., perceptions of low behavioral control) are deeply ingrained in the municipal staff, their decision to not adopt $A B$ would automatically be activated without engaging in a thorough cognitive process. In terms of perceived barriers, our results showed that municipal officers who believed that "it is difficult to have an internal budget in place to fund measures to prepare for heat waves or flooding" are less likely to act. Consequently, awareness and educational work with municipal officers could target such a belief and attempt to change it. For instance, interventions could be 
designed to counter and change a municipal officer's belief by insisting on the ideas (1) that adaptation does not always require significant resources or extensive analysis to identify new options; (2) that organizations might rely on measures already available to them to support adaptation (e.g., existing support grants); and (3) that organizational adaptation is predominantly about the process of receiving and interpreting climate change signals and therefore that the process of adaptation could easily be embedded in existing organizational processes (e.g., risk assessment, strategic planning, innovation) or in other changes at the municipal level in which the primary motivations are not necessarily related to climate change (e.g., replacement of infrastructure) [46].

Unlike other studies $[55,85,86]$, our results suggest that the perception of social norms does not contribute to the formation of municipal officers' intentions. One could assume that perceived pressures stemming from expectations on how the municipality should behave in the face of heat waves and flooding would lead its agents to act. Perhaps, in the context of Quebec's municipalities, each municipality considers its own situation to be unique (e.g., due to the availability of its resources for climate action, its geographical location, and/or its population size), which would make it difficult or irrelevant to adopt solutions applied in other municipalities. Moreover, although the population or governmental authorities could have high demands regarding a municipality's actions to prepare for heat waves or flooding, factors such as a lack of resources could prove to be a perceived barrier so important that it overshadows the influence of pressures from social norms, which could explain why municipal authorities' perception of social pressure does not have a significant effect on their intention to adopt $A B$. That is not to say that just because some TPB determinants (in this case, perceived social norms) do not contribute to the formation of a behavioral intention or influence the adoption of $\mathrm{AB}$, that interventions aiming to reinforce or change beliefs should not be developed. In fact, an intervention that succeeds, for example, in showing how similar municipalities are dealing with adaptation might modify the descriptive beliefs underlying social norms, and from there could increase the rate of adoption of an $\mathrm{AB}$.

Given the low response rate for certain groups of municipal officers, respondents may differ from non-respondents and may not be representative of the study population. Therefore, this study may be subject to selection bias. Because the study relied on selfreporting rather than objective measures, it is possible that the participants overestimated how often their municipality performs each behavior. Our assurance to the participants that their responses were anonymous was designed to discourage participants from providing what they perceived to be a socially desirable response. Nonetheless, in this regard, this study is similar to most other studies on pro-environmental behavior [87-89].

Although consistent with findings in other behavioral domains, the TPB model predicted only $22 \%$ of adaptation behavior adoption. As mentioned by Fishbein and Ajzen [84], the context in which the behavior/intervention takes place needs to be specific in order to obtain an accurate prediction. In this study, municipalities were used as the unit of analysis, while our respondents were municipal officers that may not have been aware of all actions that their municipalities had adopted to adapt to heat waves or flooding.

Similarly, we cannot rule out the possibility that variables other than those of the theory of planned behavior could improve prediction and understanding of municipal officers' adaptation behaviors. In addition, as the study directly relates to Quebec municipalities, it is reasonable to posit that our results and recommendations specifically apply to the context of Quebec municipal officers and that future studies should refine, update, and adapt the method to each context.

\section{Conclusions}

In summary, our work found that attitude toward a behavior and perceived barriers over $\mathrm{AB}$ contributed significantly to the prediction of readiness to adopt adaptation behaviors at the level of Quebec's municipalities. Other studies could determine whether variables other than municipal officers' attitudes, perceived social norms, perceived control 
or barriers over $\mathrm{AB}$, and behavioral intentions influence their decision to adopt adaptation behaviors. That being said, in order to design an effective behavioral intervention, it may be necessary in every case to conduct a preliminary study of the group one wishes to influence, in order to identify the behavioral, normative, and control beliefs linked to a specific group of behaviors.

Author Contributions: Conceptualization: P.V. and J.J.; methodology: P.V. and J.J.; validation: P.V.; formal analysis: M.T., P.V. and J.J.; investigation: J.J.; data curation: M.T.; writing-original draft preparation: J.J.; writing—review and editing: J.J., P.V. and M.T.; visualization: J.J.; supervision: P.V.; project administration: P.V. and J.J.; funding acquisition: P.V. All authors have read and agreed to the published version of the manuscript.

Funding: This research was funded by the 2013-2020 Climate Change Action Plan (http:/ /www. environnement.gouv.qc.ca/changements/plan_action/pacc2020.pdf).

Institutional Review Board Statement: The project was approved by the Ethics Committee of Université Laval (approbation number: 2015-225/24-09-2015).

Informed Consent Statement: Informed consent was obtained from all subjects involved in the study.

Data Availability Statement: The data presented in this study are available on request from the corresponding author. The data are not publicly available due to confidentiality reasons.

Acknowledgments: We gratefully acknowledge financial support from the 2013-2020 Climate Change Action Plan, funded by the Institut national de santé publique du Québec (INSPQ).

Conflicts of Interest: The authors declare no conflict of interest.

\section{References}

1. Winn, M.L.; Kirchgeorg, M.; Griffiths, A.; Linnenluecke, M.K.; Günther, E. Impacts from Climate Change on Organizations: A Conceptual Foundation. Bus. Strategy Environ. 2011, 20, 157-173. [CrossRef]

2. Gasparrini, A.; Guo, Y.; Hashizume, M.; Lavigne, E.; Tobias, A.; Zanobetti, A.; Schwartz, J.D.; Leone, M.; Michelozzi, P.; Kan, H. Changes in Susceptibility to Heat during the Summer: A Multicountry Analysis. Am. J. Epidemiol. 2016, 183, $1027-1036$. [CrossRef] [PubMed]

3. Oudin Åström, D.; Bertil, F.; Joacim, R. Heat Wave Impact on Morbidity and Mortality in the Elderly Population: A Review of Recent Studies. Maturitas 2011, 69, 99-105. [CrossRef] [PubMed]

4. Watts, N.; Adger, W.N.; Agnolucci, P.; Blackstock, J.; Byass, P.; Cai, W.; Chaytor, S.; Colbourn, T.; Collins, M.; Cooper, A.; et al. Health and Climate Change: Policy Responses to Protect Public Health. Lancet 2015, 386, 1861-1914. [CrossRef]

5. IPCC. Climate Change 2014: Impacts, Adaptation, and Vulnerability. Part A: Global and Sectoral Aspects; Contribution of Working Group II to the Fifth Assessment Report of the Intergovernmental Panel on Climate Change; Cambridge University Press: Cambridge, UK, 2014.

6. Vogel, B.; Henstra, D. Studying Local Climate Adaptation: A Heuristic Research Framework for Comparative Policy Analysis. Glob. Environ. Chang. 2015, 31, 110-120. [CrossRef]

7. The Paris Agreement; United Nations Framework Convention on Climate Change: New York, NY, USA, 2015.

8. Bulkeley, H.; Broto, V.C.; Edwards, G. Bringing Climate Change to the City: Towards Low Carbon Urbanism? Local Environ. 2012, 17, 545-551. [CrossRef]

9. Ebi, K.L.; Semenza, J.C. Community-Based Adaptation to the Health Impacts of Climate Change. Am. J. Prev. Med. 2008, 35, 501-507. [CrossRef] [PubMed]

10. Gore, C.; Robinson, P. Local Government Response to Climate Change: Our Last, Best Hope? In Changing Climates in North. American Politics: Institutions, Policymaking and Multilevel Governance; Selin, H., VanDeveer, S.D., Eds.; MIT Press: Cambridge, MA, USA, 2009; pp. 137-158. ISBN 9780262512862.

11. Henstra, D. Toward the Climate-Resilient City: Extreme Weather and Urban Climate Adaptation Policies in Two Canadian Provinces. J. Comp. Policy Anal. Res. Pract. 2012, 14, 175-194. [CrossRef]

12. Cloutier, G.; Papin, M.; Bizier, C. Do-It-Yourself (DIY) Adaptation: Civic Initiatives as Drivers to Address Climate Change at the Urban Scale. Cities 2018, 74, 284-291. [CrossRef]

13. Nalau, J.; Preston, B.L.; Maloney, M.C. Is Adaptation a Local Responsibility? Environ. Sci. Policy 2015, 48, 89-98. [CrossRef]

14. Anguelovski, I.; Chu, E.; Carmin, J. Variations in Approaches to Urban Climate Adaptation: Experiences and Experimentation from the Global South. Glob. Environ. Chang. 2014, 27, 156-167. [CrossRef]

15. Baynham, M.; Stevens, M. Are We Planning Effectively for Climate Change? An Evaluation of Official Community Plans in British Columbia. J. Environ. Plan. Manag. 2014, 57, 557-587. [CrossRef] 
16. Caron, A.; Blais, P. Les Outils d'Urbanisme Municipaux Au Service Du Développement Durable; Ministère des Affaires Municipales et des Régions: Québec, QC, Canada, 2008.

17. Henstra, D.; McBean, G. Canadian Disaster Management Policy: Moving toward a Paradigm Shift? Can. Public Policy Anal. Polit. 2005, 31, 303-318. [CrossRef]

18. Hwacha, V. Canada's Experience in Developing a National Disater Mitigation Strategy: A Deliberative Dialogue Approach. Mitig. Adapt. Strateg. Glob. Chang. 2005, 10, 507-523. [CrossRef]

19. Bassil, K.; Cole, D. Effectiveness of Public Health Interventions in Reducing Morbidity and Mortality during Heat Episodes: A Structured Review. Int. J. Environ. Res. Public Health 2010, 7, 991-1001. [CrossRef] [PubMed]

20. Chau, P.; Chan, K.; Woo, J. Hot Weather Warning Might Help to Reduce Elderly Mortality in Hong Kong. Int. J. Biometeorol. 2009, 53, 461-468. [CrossRef]

21. Das, S.; Smith, S.C. Awareness as an Adaptation Strategy for Reducing Mortality from Heat Waves: Evidence from a Disaster Risk Management Program in India. Clim. Chang. Econ. 2012, 3, 1250010. [CrossRef]

22. Fouillet, A.; Rey, G.; Wagner, V.; Laaidi, K.; Empereur-Bissonnet, P.; Le Tertre, A.; Frayssinet, P.; Bessemoulin, P.; Laurent, F.; De Crouy-Chanel, P.; et al. Has the Impact of Heat Waves on Mortality Changed in France since the European Heat Wave of Summer 2003? A Study of the 2006 Heat Wave. Int. J. Epidemiol. 2008, 37, 309-317. [CrossRef] [PubMed]

23. Jackson, L.E. The Relationship of Urban Design to Human Health and Condition. Landsc. Urban Plan. 2003, 64, 191-200. [CrossRef]

24. RTPI. Planning Horizons: Promoting Healthy Cities. Why Planning Is Critical to a Healthy Urban Future; RTPI: London, UK, 2014.

25. Lesnikowski, A.; Ford, J.; Biesbroek, R.; Berrang-Ford, L.; Heymann, S.J. National-Level Progress on Adaptation. Nat. Clim. Chang. 2015, 6, 261-264. [CrossRef]

26. Araos, M.; Berrang-Ford, L.; Ford, J.D.; Austin, S.E.; Biesbroek, R.; Lesnikowski, A. Climate Change Adaptation Planning in Large Cities: A Systematic Global Assessment. Environ. Sci. Policy 2016, 66, 375-382. [CrossRef]

27. Austin, S.E.; Ford, J.D.; Berrang-Ford, L.; Araos, M.; Parker, S.; Fleury, M.D. Public Health Adaptation to Climate Change in Canadian Jurisdictions. Int. J. Environ. Res. Public Health 2015, 12, 623-651. [CrossRef] [PubMed]

28. Stevens, M.; Senbel, M. Examining Municipal Response to a Provincial Climate Action Planning Mandate in British Columbia, Canada. Local Environ. 2012, 17, 837-861. [CrossRef]

29. Reckien, D.; Flacke, J.; Dawson, R.J.; Heidrich, O.; Olazabal, M.; Foley, A.; Hamann, J.J.-P.; Orru, H.; Salvia, M.; De Gregorio Hurtado, S.; et al. Climate Change Response in Europe: What's the Reality? Analysis of Adaptation and Mitigation Plans from 200 Urban Areas in 11 Countries. Clim. Chang. 2014, 122, 331-340. [CrossRef]

30. Poutiainen, C.; Berrang-Ford, L.; Ford, J.; Heymann, J. Civil Society Organizations and Adaptation to the Health Effects of Climate Change in Canada. Public Health 2013, 127, 403-409. [CrossRef]

31. Schwartz, E. Local Solutions to a Global Problem?: Canadian Municipal Policy Responses to Climate Change. Ph.D. Thesis, University of British Columbia, Vancouver, BC, Canada, 2016.

32. Aylett, A. Institutionalizing the Urban Governance of Climate Change Adaptation: Results of an International Survey. Urban Clim. 2015, 14, 4-16. [CrossRef]

33. Carmin, J.; Nadkarni, N.; Rhie, C. Progress and Challenges in Urban Climate Adaptation Planning: Results of a Global Survey; Massachusetts Institute of Technology (MIT): Cambridge, MA, USA, 2012; pp. 1-30.

34. Guyadeen, D.; Thistlethwaite, J.; Henstra, D. Evaluating the Quality of Municipal Climate Change Plans in Canada. Clim. Chang. 2019, 152, 121-143. [CrossRef]

35. Berkhout, F. Adaptation to Climate Change by Organizations. Wiley Interdiscip. Rev. Clim. Chang. 2012, 3, 91-106. [CrossRef]

36. Grothmann, T.; Grecksch, K.; Winges, M.; Siebenhüner, B. Assessing Institutional Capacities to Adapt to Climate Change: Integrating Psychological Dimensions in the Adaptive Capacity Wheel. Nat. Hazards Earth Syst. Sci. 2013, 13, 3369-3384. [CrossRef]

37. Carman, J.P.; Zint, M.T. Defining and Classifying Personal and Household Climate Change Adaptation Behaviors. Glob. Environ. Chang. 2020, 61, 102062. [CrossRef]

38. Clayton, S.; Devine-Wright, P.; Stern, P.C.; Whitmarsh, L.; Carrico, A.; Steg, L.; Swim, J.; Bonnes, M. Psychological Research and Global Climate Change. Nat. Clim. Chang. 2015, 5, 640-646. [CrossRef]

39. Gifford, R. The Dragons of Inaction: Psychological Barriers That Limit Climate Change Mitigation and Adaptation. Am. Psychol. 2011, 66, 290-302. [CrossRef]

40. Grothmann, T.; Patt, A. Adaptive Capacity and Human Cognition: The Process of Individual Adaptation to Climate Change. Glob. Environ. Chang. 2005, 15, 199-213. [CrossRef]

41. Mehiriz, K.; Gosselin, P. Municipalities' Preparedness for Weather Hazards and Response to Weather Warnings. PLoS ONE 2016, 11, e0163390. [CrossRef]

42. Kuhlicke, C.; Seebauer, S.; Hudson, P.; Begg, C.; Bubeck, P.; Dittmer, C.; Grothmann, T.; Heidenreich, A.; Kreibich, H.; Lorenz, D.F.; et al. The Behavioral Turn in Flood Risk Management, Its Assumptions and Potential Implications. Wires Water 2020, 7 , e1418. [CrossRef]

43. Wilson, R.S.; Herziger, A.; Hamilton, M.; Brooks, J.S. From Incremental to Transformative Adaptation in Individual Responses to Climate-Exacerbated Hazards. Nat. Clim. Chang. 2020, 10, 200-208. [CrossRef]

44. Meinel, U.; Höferl, K.-M. Non-Adaptive Behavior in the Face of Climate Change: First Insights from a Behavioral Perspective Based on a Case Study among Firm Managers in Alpine Austria. Sustainability 2017, 9, 1132. [CrossRef] 
45. Page, R.; Dilling, L. How Experiences of Climate Extremes Motivate Adaptation among Water Managers. Clim. Chang. 2020, 161, 499-516. [CrossRef]

46. Berkhout, F.; Hertin, J.; Gann, D.M. Learning to Adapt: Organisational Adaptation to Climate Change Impacts. Clim. Chang. 2006, 78, 135-156. [CrossRef]

47. Bazerman, M.H. Climate Change as a Predictable Surprise. Clim. Chang. 2006, 77, 179-193. [CrossRef]

48. Weick, K.E. Sensemaking in Organizations; Sage: Thousand Oaks, CA, USA, 1995; ISBN 978-0-8039-7177-6.

49. Jacob, J.; Valois, P.; Aenishaenslin, C.; Bouchard, C.; Briand, S.; Talbot, D.; Tessier, M. Factors Leading Municipal Authorities to Implement Preventive Interventions for Lyme Disease. Int. J. Environ. Res. Public Health 2019, 16, 1547. [CrossRef] [PubMed]

50. Ajzen, I. The Theory of Planned Behavior. Organ. Behav. Hum. Decis. Process. 1991, 50, 179-211. [CrossRef]

51. Unsworth, K.; Russel, S.V.; Lewandowsky, S.; Lawrence, C.; Fielding, K.; Heath, J.; Evans, A.; Hurlstone, M.J.; Mcneill, I.M. What about Me? Factors Affecting Individual Adaptive Coping Capacity across Different Population; National Climate Change Adaptation Research Facility: Gold Coast, Australia, 2013.

52. Chan, H.-W.; Pong, V.; Tam, K.-P. Explaining Participation in Earth Hour: The Identity Perspective and the Theory of Planned Behavior. Clim. Chang. 2020, 158, 309-325. [CrossRef]

53. Taghikhah, F.; Voinov, A.; Shukla, N.; Filatova, T. Exploring Consumer Behavior and Policy Options in Organic Food Adoption: Insights from the Australian Wine Sector. Environ. Sci. Policy 2020, 109, 116-124. [CrossRef]

54. Kim, S.; Jeong, S.-H.; Hwang, Y. Predictors of Pro-Environmental Behaviors of American and Korean Students: The Application of the Theory of Reasoned Action and Protection Motivation Theory. Sci. Commun. 2013, 35, 168-188. [CrossRef]

55. Papagiannakis, G.; Lioukas, S. Values, Attitudes and Perceptions of Managers as Predictors of Corporate Environmental Responsiveness. J. Environ. Manag. 2012, 100, 41-51. [CrossRef]

56. Sharma, P.; Sharma, S. Drivers of Proactive Environmental Strategy in Family Firms. Bus. Ethics Q. 2011, 21, 309-334. [CrossRef]

57. Ajzen, I. The Theory of Planned Behaviour: Reactions and Reflections. Psychol. Health 2011, 26, 1113-1127. [CrossRef] [PubMed]

58. Nosek, B.A.; Graham, J.; Lindner, N.M.; Kesebir, S.; Hawkins, C.B.; Hahn, C.; Schmidt, K.; Motyl, M.; Joy-Gaba, J.; Frazier, R. Cumulative and Career-Stage Citation Impact of Social-Personality Psychology Programs and Their Members. Personal. Soc. Psychol. Bull. 2010, 36, 1283-1300. [CrossRef] [PubMed]

59. Gifford, R. Environmental Psychology Matters. Annu. Rev. Psychol. 2014, 65, 541-579. [CrossRef]

60. Hambrick, D.C.; Mason, P.A. Upper Echelons: The Organization as a Reflection of Its Top Managers. Acad. Manag. Rev. 1984, 9 , 193-206. [CrossRef]

61. Zhang, F.; Welch, E.W.; Miao, Q. Public Organization Adaptation to Extreme Events: Mediating Role of Risk Perception. J. Public Adm. Res. Theory 2018, 28, 371-387. [CrossRef]

62. Daft, R.L.; Weick, K.E. Toward a Model of Organizations as Interpretation Systems. Acad. Manag. Rev. 1984, 9, 284-295. [CrossRef]

63. Linnenluecke, M.K.; Griffiths, A.; Winn, M.I. Firm and Industry Adaptation to Climate Change: A Review of Climate Adaptation Studies in the Business and Management Field. Wiley Interdiscip. Rev. Clim. Chang. 2013, 4, 397-416. [CrossRef]

64. Ajzen, I. The theory of planned behavior. In Handbook of Theories of Social Psychology; Lange, P.A.M., Kruglanski, A.W., Higgins, E.T., Eds.; Sage: London, UK, 2012; Volume 1, pp. 438-459. ISBN 9781847875143.

65. Ajzen, I. From intentions to actions: A theory of planned behavior. In Action-Control: From Cognition to Behavior; Kuhl, J., Beckman, J., Eds.; Springer: Heidelberg, Germany, 1985; pp. 11-39. ISBN 978-3-642-69746-3.

66. MAMOT. L'organisation Municipale au Québec En 2016; Ministère des Affaires Municipales et de l'Occupation du Territoire: Québec, QC, Canada, 2016.

67. Rauken, T.; Mydske, P.K.; Winsvold, M. Mainstreaming Climate Change Adaptation at the Local Level. Local Environ. 2015, 20, 408-423. [CrossRef]

68. Anisuzzaman, M.; Jennings, P. A Framework for Mainstreaming Climate Change Adaptation within Local Government Operations. Int. J. Clim. Chang. Impacts Responses 2012, 3, 31-46. [CrossRef]

69. Juhola, S. Mainstreaming climate change adaptation: The case of multi-level governance in Finland. In Developing Adaptation Policy and Practice in Europe: Multi-Level Governance of Climate Chang.; Keskitalo, E., Ed.; Springer: Dordrecht, The Netherlands, 2010; pp. 149-187. ISBN 90-481-9324-9.

70. Huq, S.; Reid, H.; Konate, M.; Rahman, A.; Sokona, Y.; Crick, F. Mainstreaming Adaptation to Climate Change in Least Developed Countries (LDCs). Clim. Policy 2004, 4, 25-43. [CrossRef]

71. Klein, R.J.; Eriksen, S.E.; Næss, L.O.; Hammill, A.; Tanner, T.M.; Robledo, C.; O’Brien, K.L. Portfolio Screening to Support the Mainstreaming of Adaptation to Climate Change into Development Assistance. Clim. Chang. 2007, 84, 23-44. [CrossRef]

72. Bates, L.E.; Green, M.; Leonard, R.; Walker, I. The Influence of Forums and Multilevel Governance on the Climate Adaptation Practices of Australian Organizations. Ecol. Soc. 2013, 18, 62. [CrossRef]

73. Frumkin, H.; Hess, J.; Luber, G.; Malilay, J.; McGeehin, M. Climate Change: The Public Health Response. Am. J. Public Health 2008, 98, 435-445. [CrossRef] [PubMed]

74. Füssel, H.-M. Assessing Adaptation to the Health Risks of Climate Change: What Guidance Can Existing Frameworks Provide? Int. J. Environ. Health Res. 2008, 18, 37-63. [CrossRef]

75. Muthén, L.K.; Muthén, B.O. Mplus Statistical Analysis With Latent Variables User's Guide, Version 8; Muthén \& Muthén: Los Angeles, CA, USA, 2017; ISBN 0982998325.

76. Hox, J.J.; Bechger, T.M. An Introduction to Structural Equation Modeling. Fam. Sci. Rev. 1998, 11, $354-373$. 
77. Hayduk, L.; Cummings, G.; Boadu, K.; Pazderka-Robinson, H.; Boulianne, S. Testing! Testing! One, Two, Three--Testing the Theory in Structural Equation Models! Personal. Individ. Differ. 2007, 42, 841-850. [CrossRef]

78. Kline, R.B. Principles and Practice of Structural Equation Modeling, 4th ed.; Guilford Publications: New York, NY, USA, 2015; ISBN 978-1-4625-2335-1.

79. Bandalos, D.L.; Finney, S.J. Item parceling issues in structural equation modeling. In New Developments and Techniques in Structural Equation Modeling; Marcoulides, G.A., Schumacker, R.E., Eds.; Lawrence Erlbaum Associates Publishers: Mahwah, NJ, USA, 2001; pp. 269-296. ISBN 978-0-8058-3593-9.

80. Hu, L.; Bentler, P.M. Cutoff Criteria for Fit Indexes in Covariance Structure Analysis: Conventional Criteria versus New Alternatives. Struct. Equ. Modeling A Multidiscip. J. 1999, 6, 1-55. [CrossRef]

81. Valois, P.; Talbot, D.; Bouchard, D.; Renaud, J.-S.; Caron, M.; Canuel, M.; Arrambourg, N. Using the Theory of Planned Behavior to Identify Key Beliefs Underlying Heat Adaptation Behaviors in Elderly Populations. Popul. Environ. 2020, 41, 480-506. [CrossRef]

82. Feinstein, N.W.; Mach, K.J. Three Roles for Education in Climate Change Adaptation. Clim. Policy 2020, 20, 317-322. [CrossRef]

83. Von Bülow, C.W.; Liu, X. Ready-Made OTree Applications for the Study of Climate Change Adaptation Behavior. J. Behav. Exp. Econ. 2020, 88, 101590. [CrossRef]

84. Fishbein, M.; Ajzen, I. Predicting and Changing Behavior: The Reasoned Action Approach; Psychology Press: New York, NY, USA, 2010; ISBN 9780805859249.

85. Van der Linden, S. The Social-Psychological Determinants of Climate Change Risk Perceptions: Towards a Comprehensive Model. J. Environ. Psychol. 2015, 41, 112-124. [CrossRef]

86. Van Valkengoed, A.M.; Steg, L. Meta-Analyses of Factors Motivating Climate Change Adaptation Behaviour. Nat. Clim. Chang. 2019, 9, 158-163. [CrossRef]

87. Bakhsh, K.; Rauf, S.; Zulfiqar, F. Adaptation Strategies for Minimizing Heat Wave Induced Morbidity and Its Determinants. Sustain. Cities Soc. 2018, 41, 95-103. [CrossRef]

88. Bichard, E.; Kazmierczak, A. Are Homeowners Willing to Adapt to and Mitigate the Effects of Climate Change? Clim. Chang. 2012, 112, 633-654. [CrossRef]

89. Liu, T.; Xu, Y.J.; Zhang, Y.H.; Yan, Q.H.; Song, X.L.; Xie, H.Y.; Luo, Y.; Rutherford, S.; Chu, C.; Lin, H.L.; et al. Associations between Risk Perception, Spontaneous Adaptation Behavior to Heat Waves and Heatstroke in Guangdong Province, China. BMC Public Health 2013, 13, 913. [CrossRef] [PubMed] 